\title{
Selective colorimetric sensors for cyanide and acetate ion in partially aqueous medium
}

\author{
Divya Singhal, Neha Gupta, Ashok Kumar Singh* \\ Department of Chemistry, Indian Institute of Technology Roorkee \\ Roorkee-247667, India \\ *E-mail: akscyfcy@iitr.ernet.in
}

\begin{abstract}
$\underline{\text { Abstract }}$
4-(thiazol-2-yldiazenyl)phenol $\left(\mathrm{L}_{1}\right)$ and 2-((4-hydroxyphenyl) diazenyl)-5-nitrophenol $\left(\mathrm{L}_{2}\right)$ based on azo phenol were synthesised and used as selective colorimetric sensor for $\mathrm{CN}^{-}$and $\mathrm{AcO}^{-}$ion in DMSO/H $\mathrm{H}_{2} \mathrm{O}-\mathrm{HEPES}(\mathrm{v} / \mathrm{v} ; 1: 1, \mathrm{pH}-7.3 \pm 0.2$ ) and showed good sensitivity with large red shifts and nanomolar detection limit for $\mathrm{CN}^{-}$and $\mathrm{AcO}^{-}$ion. The stoichiometry of $\mathrm{L}_{1}$ with $\mathrm{CN}^{-} / \mathrm{AcO}^{-}$ion was found to be $1: 1$ and $\mathrm{L}_{2}$ with $\mathrm{CN}^{-} / \mathrm{AcO}^{-}$ion was found to be 1:2. Binding constant for $\mathrm{L}_{1}+\mathrm{CN}^{-}, \mathrm{L}_{1}+\mathrm{AcO}^{-}, \mathrm{L}_{2}+\mathrm{CN}^{-}$and $\mathrm{L}_{2}+\mathrm{AcO}^{-}$were calculated by $\mathrm{B}-\mathrm{H}$ plot as $1.6 \times 10^{3}, 8.0 \times 10^{2}, 8.4 \times 10^{3}$ and $1.7 \times 10^{2}$ respectively. $\mathrm{L}_{2}$ showed high selectivity towards $\mathrm{CN}^{-}$ion with low detection limit of $81 \mathrm{nM}$ and large binding constant. In addition, ${ }^{1} \mathrm{H}$ NMR titration and DFT studies also supported the deprotonation mechanism of receptors in the presence of selective anions.
\end{abstract}

Keywords: Chemosensors, $\mathrm{CN}^{-}$selective sensor, Test strip sensor 


\section{Introduction}

In supramolecular chemistry, the development of chromogenic sensor is of great interest in anion sensing due to their chemical and biological applications [1]. The most hazardous cyanide ion widely used in the various chemical industries $(140,000$ tons of cyanide per year) causes the severe pollution of water supplies [2-3]. Cyanide is extremely toxic, increases environmental pollution due to its industrial use mainly production of textiles, papers and plastics. Importantly, cyanide rigorously suppresses the transport of oxygen as it binds with cytochrome c oxidase and effects electron transfer from cytochrome c oxidase to oxygen in mitochondria [4]. Acetate ion is more important in living organisms as acetyl coenzyme [5].

There are many conventional detection methods for quantitative determination of cyanide and acetate ion mainly based on electrochemical and voltammetric techniques [6-10]. Due to their cost and sophisticated instruments, detection of cyanide and acetate ion by absorption or fluorescence or both studies are easier and growing very fast [11-15]. So the development of colorimetric anion sensor is more attractive due to no requirement of expensive equipment as color changes can be easily detected by the naked-eye. Generally, the chromogenic anion sensor consisted many pathways as: displacement of a metal complex (Fig. 1), anion receptor and chromophore, these sensors having chromogenic centre that is covalently bonded to the receptor unit. The receptor unit or binding sites are based on hydrogen bond donor group, generally $-\mathrm{OH}$ and $-\mathrm{NH}$ group of phenols, sulphonamide, urea, thiourea [16-19]. Compared to the above traditional chemosensor method, an alternative chemodosimeter approach based on an irreversible specific chemical reaction has emerged as an active research area of significant importance. However, considerable efforts have been devoted to the development of a chemodosimeter for anions. Many examples are available about colorimetric sensors for acetate and cyanide ion in the literatures [20-28].

In this paper, we described two phenol based azo dyes $L_{1}$ and $L_{2}$ which selectively sense biologically important $\mathrm{CN}^{-}$and $\mathrm{AcO}^{-}$ion in partially aqueous medium without any interference of different anions. Two azo dye based ligands were synthesised having phenolic group for better sensing ability towards anions, resulting in the enhancement of push-pull approach of intramolecular charge transfer (ICT), which reproduced red-shifted absorption. Azo dye ligand $\mathrm{L}_{2}$ with $-\mathrm{NO}_{2}$ units (electron-withdrawing substituent) performed high selective binding ability towards cyanide ion over other studied ion. 


\section{Experimental Section}

\subsection{Reagents and Instruments}

Analytical grade anion salts are purchased from Merck. Phenol, 2-aminothiazole and 2amino-5-nitrophenol were purchased from Sigma-Aldrich. CHNS analysis was recorded on an Elementar model Vario EL-III. IR spectra were obtained using a Perkin Elmer FT-IR 1000 spectrophotometer as films between $\mathrm{KBr} .{ }^{1} \mathrm{H}$ NMR spectra were recorded on Bruker AVANCE $500 \mathrm{MHz}$ spectrometer and Zeol $400 \mathrm{MHz}$ spectrometer. UV-vis spectra were recorded on Shimadzu, UV-3600 double beam spectrophotometer using $10 \mathrm{~mm}$ path length of silica cell. DFT computational studies were obtained with Gaussian 09 W programme in gas phase using a B3LYP function with 6-31G(d,p) basis set for $\mathrm{L}_{1}, \mathrm{~L}_{2}, \mathrm{~L}_{1}+\mathrm{CN}^{-}$and $\mathrm{L}_{2}+\mathrm{CN}^{-}$.

\subsection{Results and Discussion}

\subsubsection{Synthesis of Azo dyes:}

\section{Synthesis of 4-(thiazol-2-yldiazenyl)phenol $\left(L_{1}\right)$}

4-(thiazol-2-yldiazenyl)phenol $\left(\mathrm{L}_{1}\right)$ was synthesised based on the previously reported literature [29]. $1 \mathrm{gm}$ of 2-aminothiazole was dissolved in $12 \mathrm{ml} \mathrm{of} \mathrm{H}_{2} \mathrm{SO}_{4}$ and then add 0.3 gm of sodium nitrite $\left(\mathrm{NaNO}_{2}\right)$ in $10 \mathrm{ml}$ water in dropwise manner with continuous stirring. The mixture was stirred for half an hour at $0^{\circ} \mathrm{C}$ (Solution 1). For the coupling reaction, the mixture of $0.9 \mathrm{gm}$ of phenol and $10 \mathrm{ml}$ of $0.1 \mathrm{M} \mathrm{NaOH}$ were taken in a separate flask and maintain the temperature at $0^{\circ} \mathrm{C}$ (Solution 2). Solution 2 was added in solution 1 while stirring at $0^{\circ} \mathrm{C}$. The formed precipitate washed with distilled water and recrystallised using ethanol and collect the orange powdered product (Scheme 1).

Yield-60 \%; $\mathrm{C}_{9} \mathrm{H}_{7} \mathrm{~N}_{3} \mathrm{OS} ; \mathrm{C}, 52.67 ; \mathrm{H}, 3.44 ; \mathrm{N}, 20.47 ; \mathrm{O}, 7.80 ; \mathrm{S}, 15.62$; found C, 52.26; H, 3.4; N, 20.40; O, 8.0; S, 15.94; FTIR (KBr, $v_{\max }, \mathrm{cm}^{-1}$ )-OH: 3436, -N-N, 1591, C-O: 1242 , Ar-H: 1143, ${ }^{1} \mathrm{H}$ NMR (500 MHz, DMSO-d6, ppm); $\delta 10.796$ (s, 1H), 8.046 (d, 1H), 7.862 (d, 2H), $7.818(\mathrm{~d}, 1 \mathrm{H}), 6.983(\mathrm{~d}, 2 \mathrm{H}),{ }^{13} \mathrm{C}$ NMR (100 MHz, DMSO-d6): 117.1, 122.3, 126.7, 131.0, 131.6, 144.1, 144.8, 163.4, 177.2 ppm; UV-vis (DMSO, $\lambda_{\max }, \mathrm{nm}$ ); 253, 393. [ESI Fig.1 - ESI Fig.7]

\section{2-((4-hydroxyphenyl)diazenyl)-5-nitrophenol $\left(\mathrm{L}_{2}\right)$}

Took, 2 gm of 2-amino-5-nitrophenol and dissolved in $24 \mathrm{ml}$ of $\mathrm{H}_{2} \mathrm{SO}_{4}$ and then add $0.6 \mathrm{gm}$ of sodium nitrite $\left(\mathrm{NaNO}_{2}\right)$ in $10 \mathrm{ml}$ water in dropwise manner on continuous stirring. The mixture was stirred for half hour at $0^{\circ} \mathrm{C}$ (Solution 1). For the coupling reaction, the mixture of 
$1.8 \mathrm{gm}$ of phenol and $10 \mathrm{ml}$ of $0.2 \mathrm{M} \mathrm{NaOH}$ were taken in a separate flask and mentain the temperature of this solution at $0^{\circ} \mathrm{C}$ (Solution 2). Solution 2 was added slowly on stirring at $0^{\circ} \mathrm{C}$ to the solution 1 . The occurred precipitate washed with distilled water and recrystallised by ethanol and collect yellow-orange powder (Scheme 1).

Yield-51 \%; $\mathrm{C}_{12} \mathrm{H}_{9} \mathrm{~N}_{3} \mathrm{O}_{4} ; \mathrm{C}, 55.60 ; \mathrm{H}, 3.50 ; \mathrm{N}, 16.21 ; \mathrm{O}, 24.69$; found C, 56.30; H, 3.47; N, 16.27.40; O, 23.96; FTIR (KBr, $\left.v_{\max }, \mathrm{cm}^{-1}\right)-\mathrm{OH} ; 3429$, -N-N; 1585, 1401, Ar-H; 1186; ${ }^{1} \mathrm{H}$ NMR (500 MHz, DMSO-d6, ppm); $\delta 10.884$ (s, 1H), 8.973 (s, 1H), 7.445 (m, 2H), 7.051 (d, 1H), $6.988(\mathrm{~s}, 1 \mathrm{H}), 6.883(\mathrm{~d}, 1 \mathrm{H}), 6.688(\mathrm{~d}, 2 \mathrm{H}) ;{ }^{13} \mathrm{C}$ NMR (100 MHz, DMSO-d 6 , ppm) 120.6, 121.9, 122.6, 127.0, 128.9, 129.6, 130.1, 132.1, 141.3, 143.3, 165.3, 172.4; UV-vis (DMSO, $\left.\lambda_{\max }, \mathrm{nm}\right) ; 213,262,374$.[ESI Fig.1 - ESI Fig.7]

\subsubsection{Naked Eye Experiments:}

The recognition and chromogenic sensing ability of azo dye $\mathrm{L}_{1}$ and $\mathrm{L}_{2}(20 \mu \mathrm{M})$ were checked with the sodium salt of a series of anions $\mathrm{F}^{-}, \mathrm{Cl}^{-}, \mathrm{Br}^{-}, \mathrm{CN}^{-}, \mathrm{H}_{2} \mathrm{PO}_{4}^{-}, \mathrm{HPO}_{4}{ }^{2-}, \mathrm{SO}_{4}{ }^{2-}, \mathrm{SO}_{3}^{2-}, \mathrm{AcO}^{-}$ , $\mathrm{N}_{3}{ }^{-}$and $\mathrm{SCN}^{-}(200 \mu \mathrm{M})$ in DMSO/H $\mathrm{H}_{2} \mathrm{O}$-HEPES (v/v; 1:1, $\left.\mathrm{pH}=7.3 \pm 0.2\right)$ solution. By examine the chromogenic properties of azo dyes $\mathrm{L}_{1}$ and $\mathrm{L}_{2}$, it was found that both ligands showed instant color changes from yellow to violet with more basic anion, $\mathrm{CN}^{-} / \mathrm{AcO}^{-}$and other anions showed no such color changes (Fig. 2). Basicity of anions is known to be in order of $\mathrm{CN}^{-}>\mathrm{AcO}^{-}>\mathrm{N}_{3}^{-}>\mathrm{F}^{-}>\mathrm{H}_{2} \mathrm{PO}_{4}^{-}>\mathrm{Cl}^{-}>\mathrm{Br}^{-}>\mathrm{I}^{-}[30]$ and the ability to form hydrogen bond in order of $\mathrm{F}^{-}>\mathrm{AcO}^{-}>\mathrm{H}_{2} \mathrm{PO}_{4}^{-}>\mathrm{N}_{3}^{-}>\mathrm{CN}^{-}$so that both anions with more basic and least H-bonding character might deprotonate the phenolic hydrogen rather than forming $\mathrm{H}$-bonding. Further the sensitivity of azo dyes with $\mathrm{CN}^{-}$and $\mathrm{AcO}^{-}$ion was analysed by absorption spectra.

\subsubsection{UV-Vis Analysis:}

Upon addition of different anion like $\mathrm{F}^{-}, \mathrm{Cl}^{-}, \mathrm{Br}^{-}, \mathrm{AcO}^{-}, \mathrm{HPO}_{4}{ }^{2-}, \mathrm{H}_{2} \mathrm{PO}_{4}{ }^{-}, \mathrm{CN}^{-}$and $\mathrm{N}_{3}{ }^{-}(200$ $\mu \mathrm{M})$, changes in UV-vis absorption spectra of $\mathrm{L}_{1}$ and $\mathrm{L}_{2}(20 \mu \mathrm{M})$ with $\mathrm{CN}^{-} / \mathrm{AcO}^{-}$ions were found. Azo dye $L_{1}$ exhibited two absorption peak at $253\left(\pi-\pi^{*}\right.$ transition), $393 \mathrm{~nm}\left(\mathrm{n}-\pi^{*}\right.$ transition) and $\mathrm{L}_{2}$ exhibited three absorption peak at $213\left(\sigma-\sigma^{*}\right.$ transition), $262\left(\pi-\pi^{*}\right.$ transition) and $374 \mathrm{~nm}$ ( $\mathrm{n}-\pi^{*}$ transition). $\mathrm{L}_{1}$ showed new absorption band with $\mathrm{CN}^{-}$and $\mathrm{AcO}^{-}$ ion at 486 and $483 \mathrm{~nm}$ respectively hence $\mathrm{L}_{2}$ also showed same behaviour with $\mathrm{CN}^{-}$and $\mathrm{AcO}^{-}$ ion and found a new absorption band at 435 and $437 \mathrm{~nm}$ respectively. With this absorption studies, it was confirmed that both azo dye ligands selectively detect cyanide and acetate ion. This new absorption band may occur because of the abstraction of proton with cyanide and acetate ion. The titrations of $\mathrm{L}_{1}(20 \mu \mathrm{M})$ were performed in DMSO/ $\mathrm{H}_{2} \mathrm{O}-\mathrm{HEPES}(\mathrm{v} / \mathrm{v} ; 1: 1$, 
$\mathrm{pH}=7.3 \pm 0.2)$ solution with $\mathrm{CN}^{-}$and $\mathrm{AcO}^{-}$ion. For the titration, a series of spectra were taken and started by adding the little amount of the anion solution with the help of microsyringe in the quartz cuvettes containing the solution of azo dye (Fig. 3a-3b). The series of UV-vis spectra were taken after each addition and absorbance values were recorded. $\mathrm{L}_{1}$ exhibits changes in absorption spectra upon addition of $\mathrm{CN}^{-}$ion, the band at $393 \mathrm{~nm}$ were quenched with consequently increases in the absorption band at $486 \mathrm{~nm}$ due to interaction of $\mathrm{CN}^{-}$ion with ligand. Titration experiments for $\mathrm{L}_{2}$ with $\mathrm{CN}^{-}$and $\mathrm{AcO}^{-}$ion was performed in the same way (Fig. 4a-4b). The absorption spectra of $L_{2}$ shown the changes upon addition of $\mathrm{CN}^{-}$ion, the band at $374 \mathrm{~nm}$ were quenched with consequently increases in absorbance at 435 $\mathrm{nm}$ due to interaction of $\mathrm{CN}^{-}$ion with ligand. Three isosbestic point were found and showed that free azo dye and adduct (dye + anion) was in equilibrium $\left(\mathrm{L}_{1}+\mathrm{CN}^{-} ; 417,301,258\right.$; $\left.\mathrm{L}_{1}+\mathrm{AcO}^{-} ; 433,298,267 ; \mathrm{L}_{2}+\mathrm{CN}^{-} ; 400,300,270 ; \mathrm{L}_{2}+\mathrm{AcO}^{-} ; 399,301,273\right)$. The binding constant of $\mathrm{CN}^{-}$and $\mathrm{AcO}^{-}$ion with $\mathrm{L}_{1}$ and $\mathrm{L}_{2}$ was calculated using $\mathrm{BH}$-plot (Inset; Fig. 3 and 4) and found to be $1.6 \times 10^{3}, 8.0 \times 10^{2}, 8.4 \times 10^{3}$, and $1.7 \times 10^{2}$ respectively. The most important parameter of chemosensor, limit of detection, for cyanide and acetate ion by using $\mathrm{L}_{1}$ and $\mathrm{L}_{2}$ were also determined from absorption titrations based on reported procedure [3132]. The obtained results from absorption titrations were normalised between maximum and minimum absorbance intensities. A plot of $\left(\mathrm{A}-\mathrm{A}_{\min } / \mathrm{A}_{\max }-\mathrm{A}_{\min }\right) \mathrm{vs} \log \mathrm{A}^{-}\left(\mathrm{A}=\mathrm{CN}^{-}, \mathrm{AcO}^{-}\right)$in DMSO- $\mathrm{H}_{2} \mathrm{O}(1: 1, \mathrm{v} / \mathrm{v})$ gave a linear curve and the point at which linear line crossed to $\mathrm{x}$-axis was familiar to detection limit (ESI Fig. 8). Table 1 lists the detection limit of $\mathrm{CN}^{-}$and $\mathrm{AcO}^{-}$ ions presented by $\mathrm{L}_{1}$ and $\mathrm{L}_{2}$. The detection limit in $\mathrm{DMSO}-\mathrm{H}_{2} \mathrm{O}(1: 1, \mathrm{v} / \mathrm{v})$ was determined to be $87 \mathrm{nM}\left(\mathrm{L}_{1}+\mathrm{CN}^{-}\right), 83 \mathrm{nM}\left(\mathrm{L}_{1}+\mathrm{AcO}^{-}\right), 81 \mathrm{nM}\left(\mathrm{L}_{2}+\mathrm{CN}^{-}\right), 89 \mathrm{nM}\left(\mathrm{L}_{2}+\mathrm{AcO}^{-}\right)$respectively. 1:1 stoichiometry of the formation of adducts between anion $\left(\mathrm{CN}^{-}\right.$and $\left.\mathrm{AcO}^{-}\right)$and azo dye $\mathrm{L}_{1}$. 1:2 stoichiometry between anions $\left(\mathrm{CN}^{-}\right.$and $\left.\mathrm{AcO}^{-}\right)$and azo dye $\mathrm{L}_{2}$ was found by Job's plot analysis. A plot was obtained by recording the absorbance of equimolar solution $(50 \mu \mathrm{M}$ in DMSO/ $\mathrm{H}_{2} \mathrm{O}, 1: 1$, v/v solution) of azo dyes and anion with different mole fraction which show 1:1 stoichiometry of $\mathrm{L}_{1}+\mathrm{CN}^{-}, \mathrm{L}_{1}+\mathrm{AcO}^{-}, \mathrm{L}_{2}+\mathrm{CN}^{-}$and $\mathrm{L}_{2}+\mathrm{AcO}^{-}$(ESI Fig. 9-10).

\subsubsection{Intereference study on sensor performance:}

As we use the both azo dyes for the detection of cyanide and acetate ion, we also tested the absorption response of $\mathrm{L}_{1}$ and $\mathrm{L}_{2}$ towards various anions $\left(\mathrm{N}_{3}{ }^{-}, \mathrm{HPO}_{4}{ }^{2-}, \mathrm{H}_{2} \mathrm{PO}_{4}^{-}, \mathrm{SCN}^{-}, \mathrm{AsO}_{2}{ }^{-}\right.$, $\mathrm{Cl}^{-}, \mathrm{Br}^{-}, \mathrm{SO}_{4}{ }^{2-}, \mathrm{SO}_{3}{ }^{2-}, \mathrm{NO}_{2}^{-}, \mathrm{NO}_{3}{ }^{-}$and $\left.\mathrm{F}^{-}\right)$and we found that there was no significant changes in the absorption spectra in the presence of various anions under the same conditions. $\mathrm{L}_{1}$ and $\mathrm{L}_{2}$ were found to be more selective towards cyanide and acetate ion even in presence of 
various other anions (Fig. 5). We have done competitive experiments [33] in the presence of detecting anion $(100 \mu \mathrm{M})$ and other anions $(100 \mu \mathrm{M})$ with azo dyes $(20 \mu \mathrm{M})$ and we found that the absorption spectra of azo dyes with detecting anions remained unaffected with the addition of other anions. This demonstrated that both azo dyes could be used to quantitative detection of cyanide and acetate ion concentration with great selectivity. In the figure 5-a and $5-b$, the blue bar indicates the absorption intensity of $\mathrm{CN}^{-}$with azo dye $\mathrm{L}_{1}$ and $\mathrm{L}_{2}$ and the red bar indicates the absorption intensity of azo dyes with $\mathrm{CN}^{-}$ion in the presence of interfering ions.

\subsection{5. ${ }^{1}$ H-NMR titration:}

To know the mechanism of interaction between azo dye and cyanide ion, ${ }^{1} \mathrm{H}$ NMR spectra of $\mathrm{L}_{1}$ and $\mathrm{L}_{2}$ were recorded in absence and presence of cyanide ion. $\mathrm{L}_{1}$ shows NMR peak at $\delta$ $10.796 \mathrm{ppm}$ for $-\mathrm{OH}$ proton and azo dye $\mathrm{L}_{2}$ shows NMR peak at $10.884 \mathrm{ppm}$ and $8.973 \mathrm{ppm}$ for hydroxy protons and the rest peak of NMR assigned for aromatic region. After adding $\mathrm{CN}^{-}$ion solution to $\mathrm{L}_{1}$ and $\mathrm{L}_{2}$, shake the solution for a while and ${ }^{1} \mathrm{H} \mathrm{NMR}$ at room temperature were taken which showed all the peaks of NMR were shifted to the upfield region in both azo dye due to the abstraction of phenolic proton or formation of phenolate ion which increased the electronegativity on $\pi-\mathrm{e}^{-}$cloud of aromatic region. The peak of $-\mathrm{OH}$ proton of (10.796 ppm) $\mathrm{L}_{1}$ and (10.884 and $\left.8.973 \mathrm{ppm}\right) \mathrm{L}_{2}$ was found to be completely disappeared and aromatic proton signals of $L_{1}$ and $L_{2}$ slightly shifted to upfield region $(\Delta \delta=$ $0.1 \mathrm{ppm}$ and $0.08 \mathrm{ppm}$ respectively). When adding more amount of $\mathrm{CN}^{-}$ion solution, aromatic protons of $L_{1}$ and $L_{2}$ were dramatically shifted into a high field region $(\Delta \delta=0.2$ ppm and $0.17 \mathrm{ppm}$ ) due to the possible phenolate ion formation. The ${ }^{1} \mathrm{H}$ NMR studies, clearly illustrated that the both $\mathrm{L}_{1}$ and $\mathrm{L}_{2}$ were interacted cyanide ion via. deprotonation of $-\mathrm{OH}$ group (Fig. 6 and 7). From the careful analysis of ${ }^{1} \mathrm{H}$ NMR spectra, the colorimetric change could take place partly through proton abstraction. We reasoned that the basic cyanide anions $(\mathrm{pKa}<9.4)$ are expected to readily abstract the acidic proton of $\mathrm{OH}$ group $(\mathrm{pKa}<4)$.

\subsubsection{Theoretical Calculations:}

To understand the recognition behaviour of phenol based azo dyes $L_{1}$ and $L_{2}$ with cyanide ion, theoretical studies have been done. The optimizied geometry of $\mathrm{L}_{1}, \mathrm{~L}_{2}, \mathrm{~L}_{1}+\mathrm{CN}^{-}$and $\mathrm{L}_{2}+\mathrm{CN}^{-}$was obtained in gas phase on Gaussian $09 \mathrm{~W}$ computational program [34]. HOMO (Highest Occupied Molecular Orbital) and LUMO (Lowest Unoccupied Molecular Orbital) of $\mathrm{L}_{1}, \mathrm{~L}_{2}, \mathrm{~L}_{1}+\mathrm{CN}^{-}$and $\mathrm{L}_{2}+\mathrm{CN}^{-}$obtained by optimised geometry and found that the free ligands $\mathrm{L}_{1}$ and $\mathrm{L}_{2}$ have higher energy gap $(\Delta \mathrm{E}=2.362$ and $2.236 \mathrm{eV}$ respectively) between 
HOMO and LUMO then the adduct $\mathrm{L}_{1}+\mathrm{CN}^{-}$and $\mathrm{L}_{2}+\mathrm{CN}^{-}(\Delta \mathrm{E}=1.865$ and $1.773 \mathrm{eV}$ respectively, Table 2). These computational calculations were performed using Gaussian 09 with B3LYP/6-31G (d,p) basis set. The deprotonation of $\mathrm{OH}$ proton of $\mathrm{L}_{1}$ and $\mathrm{L}_{2}$ concludes the decrease in energy gap of $\mathrm{L}_{1}+\mathrm{CN}^{-}$and $\mathrm{L}_{2}+\mathrm{CN}^{-}$. The theoretical calculation leads to the success of experimental results. Fig. 8 shows the optimized structure and Fig. 9 shows HOMO-LUMO energy level diagram of $\mathrm{L}_{1}, \mathrm{~L}_{2}$ and their cyanide adduct.

\subsubsection{Measurement of Anions with Test strips:}

The test strips were prepared by immersing the whatman filter paper in DMSO solution of azo dye $L_{1}$ and $L_{2}$. The paper strips were subsequently dried in air to figure out the "dipstick" method suitability for the detection of both anions [35]. The coated test strips were further immersed in the aqueous solution of $\mathrm{CN}^{-}$and $\mathrm{AcO}^{-}$ion solution of different concentration and suddenly a fast color change was found from light yellow to violet red (Fig. 10). The development of such a "dip-stick" approach is extremely attractive for "in-thefield" measurements as it does not require any additional equipment.

\subsubsection{Fast Response}

To know the fast response time of chemosensor $L_{1}$ and $L_{2}$ towards cyanide ion, changes in absorption spectra was monitored with time. In this sensor, detection of $\mathrm{CN}^{-}$ion with $\mathrm{L}_{1}$ and $\mathrm{L}_{2}$ was found to be very fast. New absorption band of $\mathrm{L}_{1}$ and $\mathrm{L}_{2}$ with $\mathrm{CN}^{-}$ion was found at the higher intensity (plateau region) within $10 \mathrm{~s}$ and remains stable for 8-11 min. A curve between time v/s ratiometric absorption intensity reveals that reaction was completed in $10 \mathrm{~s}$ (Fig. 11).

\subsubsection{Analytical Application}

To know the applicability of the sensor $L_{1}$ and $L_{2}$, it was further used for the quantitative determination of cyanide ion in drinking water. The sample of drinking water was prepared by adding a known amount of cyanide ion $(2 \mu \mathrm{M})$. The experiments were performed using absorption spectra of $2 \mathrm{ml}$ volume of sensor sample after adding a known concentration of cyanide ion which found within the linear calibration range. The experiment was repeated three times and the average concentration of cyanide ion in drinking water was found to be $1.9 \mu \mathrm{M}$. Then, the recovery percentage performed well with relative standard deviation lower than $2 \%$. 


\section{Conclusion}

Highly selective chromogenic azo dyes $\mathrm{L}_{1}$ and $\mathrm{L}_{2}$ was designed that can detect both $\mathrm{CN}^{-}$and $\mathrm{AcO}^{-}$ion in $50 \%$ aqueous medium via proton abstraction. The stoichiometry of $\mathrm{L}_{1}$ and $\mathrm{L}_{2}$ with $\mathrm{CN}^{-} / \mathrm{AcO}^{-}$ion was confirmed in account of Job's plot. i.e. 1:1 and 1:2 respectively. The more basic cyanide and acetate ion abstract the more acidic proton of the molecule and allow the formation of phenolate ion. Thus the accumulation of the negative charge on the whole molecule exhibited a large significant red shift in CT band and major changes in color. LOD for $\mathrm{CN}^{-}$ion with $\mathrm{L}_{1}$ and $\mathrm{L}_{2}$ was found to be 87 and $81 \mathrm{nM}$ and for $\mathrm{AcO}^{-}$ion with $\mathrm{L}_{1}$ and $\mathrm{L}_{2}$ was found to be 83 and $89 \mathrm{nM}$ respectively. Therefore, the system used to detect the WHO suggested maximum allowed cyanide concentration in drinking water $(1.9 \mathrm{mM})$.

\section{Acknowledgement}

Ms. Divya Singhal is highly thankful to CSIR New Delhi for financial support to undertake this work. 


\section{References:}

1. M. Inouye, 6-Functional dyes for molecular recognition: chromogenic and fluorescent receptors, Color. Non-Text. Appl. (2000) 238-274.

2. H. Hachiya, S. Ito, Y. Fushinuki, T. Masadome, Y. Asano and T. Imato, Continuous monitoring for cyanide in waste water with a galvanic hydrogen cyanide sensor using a purge system, Talanta 48 (1999) 997-1004.

3. R. Koenig, Wildlife deaths are a grim wake-up call in Eastern Europe, Science 287 (2000) 1737-1738.

4. K. W. Kulig, Cyanide Toxicity, U.S. Department of Health and Human Services, Atlanta, GA (1991).

5. Y. H. Qiao, H. Lin, J. Shao and H. K. Lin, A highly selective naked-eye colorimetric sensor for acetate ion based on 1,10-phenanthroline-2,9-dicarboxyaldehyde-di-(psubstitutedphenyl-hydrazone), Spectrochim. Acta Part A 72 (2009) 378-381.

6. V. K. Rao, S. R. Suresh, N. B. S. N. Rao and P. Rajaram, An electrochemical sensor for detection of hydrogen cyanide gas, Bull. Electrochem. 13 (1997) 327-329.

7. T. Suzuki, A. Hiolki and M. Kurahashi, Development of a method for estimating an accurate equivalence point in nickel titration of cyanide ions, Anal. Chim. Acta 476 (2003) 159-165.

8. D. Shan, C. Mousty and S. Cosnier, Subnanomolar cyanide detection at polyphenol oxidase/clay Biosensors, Anal. Chem. 76 (2004) 178-183.

9. T. T. Christison and J. S. Rohrer, Direct determination of free cyanide in drinking water by ion chromatography with pulsed amperometric detection, J. Chromatogr., A 1155 (2007) 31-39.

10. A. Safavi, N. Maleki and H. R. Shahbaazi, Indirect determination of cyanide ion and hydrogen cyanide by adsorptive stripping voltammetry at a mercury electrode, Anal. Chim. Acta 503 (2014) 213-221.

11. M. Dong, Y. Peng, Y. Dong, N. Tang and Y. Wang, A selective, colorimetric, and fluorescent chemodosimeter for relay recognition of fluoride and cyanide anions based on 1,1'-binaphthyl scaffold, Org. Lett. 14 (2012) 130-133.

12. F. Wang, L. Wang, X. Chen and J. Yoon, Recent progress in the development of fluorometric and colorimetric chemosensors for detection of cyanide ions, Chem. Soc. Rev. 43 (2014) 4312-4324. 
13. Y. Sun, Y. Liu, M. Chen and W. Guo, A novel fluorescent and chromogenic probe for cyanide detection in water based on the nucleophilic addition of cyanide to imine group, Talanta 80 (2009) 996-1000.

14. S. Y. Na and H. J. Kim, Azo dye-based colorimetric chemodosimeter for the rapid and selective sensing of cyanide in aqueous solvent, Tetrahedron Lett. 56 (2015) 493-495.

15. Y. J. Na, G. J. Park, H. Y. Jo, S. A. Lee and C. Kim, A colorimetric chemosensor based on a Schiff base for highly selective sensing of cyanide in aqueous solution: the influence of solvents, New J. Chem. 38 (2014) 5769-5776.

16. J. Shao, H. Lin, X. F. Shang, H. M. Chen and H. K. Lin, A novel neutral receptor for selective recognition of $\mathrm{H}_{2} \mathrm{PO}_{4}^{-}$, J. Incl. Phenom. Macrocycl. Chem. 59 (2007) 371-375.

17. L. Fabbrizzi, M. Licchelli, G. Rabaioli and A. Taglietti, The design of luminescent sensors for anions and ionisable analytes, Coord. Chem. Rev. 205 (2000) 85-108.

18. J. Shao, H. Lin, M. Yu, Z. Cai and H. K. Lin, Study on acetate ion recognition and sensing in aqueous media using a novel and simple colorimetric sensor and its analytical application, Talanta 75 (2008) 551-555.

19. J. Shao, H. Lin and H. K. Lin, A simple and efficient colorimetric anion receptor for $\mathrm{H}_{2} \mathrm{PO}_{4}^{-}$, Spectrochim. Acta Part A 70 (2008) 682-685.

20. S. Nishizawa, H. Kaneda, T. Uchida and N. Teramae, Anion sensing by a donor-spaceracceptor system: an intra-molecular exciplex emission enhanced by hydrogen bondmediated complexation, J. Chem. Soc., Perkin Trans. 2 (1998) 2325-2327.

21. R. Kato, S. Nishizawa, T. Hayashita and N. Teramae, A thiourea-based chromoionophore for selective binding and sensing of acetate, Tetrahedron Lett. 42 (2001) 5053-5056.

22. G. R. Youa, G. J. Park, S. A. Lee, Y. W. Choi, Y. S. Kim, J. J. Lee and C. Kim, A single chemosensor for multiple target anions: The simultaneous detection of $\mathrm{CN}^{-}$and $\mathrm{OAc}^{-}$in aqueous media, Sens. Actuators B 202 (2014) 645-655.

23. D. Udhayakumari, S. Velmathi and M. S. Boobalan, Novel chemosensor for multiple target anions: The detection of $\mathrm{F}^{-}$and $\mathrm{CN}^{-}$ion via different approach, J. Fluorine Chem. 175 (2015) 180-184.

24. Y. Sun, G. Wang and W. Guo, Colorimetric detection of cyanide with N-nitrophenyl benzamide derivatives, Tetrahedron 65 (2009) 3480-3485.

25. Y. Ding, T. Li, W. Zhu and Y. Xie, Highly selective colorimetric sensing of cyanide based on formation of dipyrrin adducts, Org. Biomol. Chem. 10 (2012) 4201-4207. 
26. M. J. Peng, Y. Guo, X. F. Yang, L. Y. Wang and J. An, A highly selective ratiometric and colorimetric chemosensor for cyanide detection, Dyes Pig. 98 (2013) 327-332.

27. X. Sun, Y. Wang, X. Zhang, S. Zhang and Z. Zhang, A new coumarin based chromofluorogenic probe for selective recognition of cyanide ions in an aqueous medium, RSC Adv. 5 (2015) 96905-96910.

28. Y. Sun, Y. Liu and W. Guo, Fluorescent and chromogenic probes bearing salicylaldehyde hydrazone functionality for cyanide detection in aqueous solution, Sens. Actuators B 143 (2009) 171-176.

29. H. Huang, F. Chen, Z. Chen and M. Jiang, Synthesis and Z-scan measurements of thirdorder optical nonlinearity of azothiazole-and azobenzothiazole-containing side-chain polymers, Polym. Bull. 73 (2016) 1545-1552.

30. J. E. Huheey, E. A. Keiter and R. L. Keiter, Inorganic chemistry: principles of structure and reactivity, Harper Collins College Publishers, New York (1993).

31. M. Shortreed, R. Kopelman, M. Kuhn and B. Hoyland, Fluorescent fiber-optic calcium sensor for physiological measurements, Anal. Chem. 68 (1996) 1414-1418.

32. Y. Ding, T. Li, W. Zhu and Y. Xie, Highly selective colorimetric sensing of cyanide based on formation of dipyrrin adducts, Org. Biomol. Chem. 10 (2012) 4201-4207.

33. V. Bhalla and R. M. Kumar, A pentaquinone based probe for relay recognition of $\mathrm{F}^{-}$and $\mathrm{Cu}^{2+}$ ions: sequential logic operations at the molecular level, Dalton Trans. 42 (2013) 13390-13396.

34. M. J. Frisch, G. W. Trucks, H. B. Schlegel, G. E. Scuseria, M. A. Robb, J. R. Cheeseman, G. Scalmani, V. Barone, B. Mennucci, G. A. Petersson, H. Nakatsuji, M. Caricato, X. Li, H. P. Hratchian, A. F. Izmaylov, J. Bloino, G. Zheng, J. L. Sonnenberg, M. Hada, M. Ehara, K. Toyota, R. Fukuda, J. Hasegawa, M. Ishida, T. Nakajima, Y. Honda, O. Kitao, H. Nakai, T. Vreven, J. A. Montgomery Jr, J. E. Peralta, F. Ogliaro, M. Bearpark, J. J. Heyd, E. Brothers, K. N. Kudin, V. N. Staroverov, R. Kobayashi, J. Normand, K. Raghavachari, A. Rendell, J. C. Burant, S. S. Iyengar, J. Tomasi, M. Cossi, N. Rega, J. M. Millam, M. Klene, J. E. Knox, J. B. Cross, V. Bakken, C. Adamo, J. Jaramillo, R. Gomperts, R. E. Stratmann, O. Yazyev, A. J. Austin, R. Cammi, C. Pomelli, J. W. Ochterski, R. L. Martin, K. Morokuma, V. G. Zakrzewski, G. A. Voth, P. Salvador, J. J. Dannenberg, S. Dapprich, A. D. Daniels, O. Farkas, J. B. Foresman, J. V. Ortiz, J. Cioslowski, and D. J. Fox, Gaussian 09, Revision A.02, Gaussian, Inc., Wallingford CT, 2009. 
35. M. S. Kumar and S. L. A. Kumar and A. Sreekanth, Highly selective fluorogenic anion chemosensors: naked-eye detection of $\mathrm{F}^{-}$and $\mathrm{AcO}^{-}$ions in natural water using a test strip, Anal. Methods 5 (2013) 6401-6410. 


\section{Figure Captions}

Scheme 1. Synthesis of 4-(thiazol-2-yldiazenyl)phenol $\mathrm{L}_{1}$ and 2-(4hydroxyphenyl)diazenyl)-5-nitrophenol $L_{2}$.

Fig.1. Illustration of "Anion Sensing". $A, A^{1}, A^{2}=$ Anions, $M=M e t a l, ~ P, P_{1}, P_{2}=$ Product, MA= ion pair.

Fig.2. Absorption spectra of $\mathrm{L}_{1}\left(20 \mu \mathrm{M}\right.$, DMSO/H $\mathrm{H}_{2} \mathrm{O}-\mathrm{HEPES}(\mathrm{v} / \mathrm{v} ; 1: 1, \mathrm{pH}=$ 7.3 \pm 0.2 ) solution) with a series of anions and sudden color change of $L_{1}$ with $\mathrm{CN}^{-}$and $\mathrm{AcO}^{-}$ion, (b) Absorption spectra of $\mathrm{L}_{2}\left(20 \mu \mathrm{M}, \mathrm{DMSO} / \mathrm{H}_{2} \mathrm{O}\right.$ HEPES (v/v; 1:1, pH = 7.3 \pm 0.2$)$ solution) with a series of anions and Sudden color change of $\mathrm{L}_{2}$ with $\mathrm{CN}^{-}$and $\mathrm{AcO}^{-}$ion.

Fig.3. (a) Absorption spectra of $\mathrm{L}_{1}\left(20 \mu \mathrm{M}\right.$, DMSO/H $\mathrm{H}_{2} \mathrm{O}-\mathrm{HEPES}(\mathrm{v} / \mathrm{v} ; 1: 1, \mathrm{pH}=$ 7.3 \pm 0.2$)$ solution) changes with increasing amount of $\mathrm{CN}^{-}$ion $(0-100 \mu \mathrm{L})$, Inset shows BH-plot of $\mathrm{L}_{1}$ with $\mathrm{CN}^{-}$ion, (b) Absorption spectra of $\mathrm{L}_{1}$ (20 $\mu \mathrm{M}, \mathrm{DMSO} / \mathrm{H}_{2} \mathrm{O}-\mathrm{HEPES}(\mathrm{v} / \mathrm{v} ; 1: 1, \mathrm{pH}=7.3 \pm 0.2)$ solution) changes with increasing amount of $\mathrm{AcO}^{-}$ion (0-100 $\left.\mu \mathrm{L}\right)$, Inset shows BH-plot of $\mathrm{L}_{1}$ with AcO $^{-}$ion.

Fig.4. (a) Absorption spectra of $\mathrm{L}_{2}\left(20 \mu \mathrm{M}\right.$, DMSO/H $\mathrm{H}_{2} \mathrm{O}-\mathrm{HEPES}(\mathrm{v} / \mathrm{v} ; 1: 1, \mathrm{pH}=$ 7.3 \pm 0.2$)$ solution) changes with increasing amount of $\mathrm{CN}^{-}$ion $(0-100 \mu \mathrm{L})$, Inset shows BH-plot of $\mathrm{L}_{2}$ with $\mathrm{CN}^{-}$ion, (b) Absorption spectra of $\mathrm{L}_{2}(20$ $\mu \mathrm{M}, \mathrm{DMSO} / \mathrm{H}_{2} \mathrm{O}-\mathrm{HEPES}(\mathrm{v} / \mathrm{v} ; 1: 1, \mathrm{pH}=7.3 \pm 0.2)$ solution) changes with increasing amount of $\mathrm{AcO}^{-}$ion $(0-100 \mu \mathrm{L})$, Inset shows BH-plot of $\mathrm{L}_{2}$ with $\mathrm{AcO}^{-}$ion.

Fig.5. (a) Interference study of different anions with the selectivity of $L_{1}$ towards $\mathrm{CN}^{-}$ion (b) Interference study of different anions with the selectivity of $\mathrm{L}_{2}$ towards $\mathrm{CN}^{-}$ion.

Fig.6. $\quad{ }^{1} \mathrm{H}-\mathrm{NMR}$ titration of $\mathrm{L}_{1}$ with $\mathrm{CN}^{-}$ion in DMSO-d${ }_{6}$.

Fig.7. ${ }^{1} \mathrm{H}-\mathrm{NMR}$ titration of $\mathrm{L}_{2}$ with $\mathrm{CN}^{-}$ion in DMSO-d${ }_{6}$.

Fig.8. Optimized structure of $L_{1}$ and $L_{2}$ and their cyanide adduct.

Fig.9. HOMO-LUMO energy diagram of $\mathrm{L}_{1}, \mathrm{~L}_{1}+\mathrm{CN}^{-}, \mathrm{L}_{2}$ and $\mathrm{L}_{2}+\mathrm{CN}^{-}$.

Fig.10. Photographs of test strips of $\mathrm{L}_{1}$ and $\mathrm{L}_{2}$ with $\mathrm{CN}^{-}$and $\mathrm{AcO}^{-}$ion.

Fig.11. (a) Absorbance changes at $485 \mathrm{~nm}$ for $\mathrm{L}_{1}\left(20 \mu \mathrm{M}, 25^{\circ} \mathrm{C}\right)$ in a mixture of DMSO- $\mathrm{H}_{2} \mathrm{O}(1: 1, \mathrm{v} / \mathrm{v})$ after addition of $\mathrm{NaCN}(1 \mathrm{mM})$ (b) Absorbance 
changes at $432 \mathrm{~nm}$ for $\mathrm{L}_{2}\left(20 \mu \mathrm{M}, 25^{\circ} \mathrm{C}\right)$ in a mixture of DMSO- $\mathrm{H}_{2} \mathrm{O}(1: 1$, v/v) after addition of $\mathrm{NaCN}(1 \mathrm{mM})$.<smiles></smiles><smiles>Nc1ccc([N+](=O)[O-])cc1OS(=O)(=O)Oc1ccc(N=Nc2ccc([N+](=O)[O-])cc2O)cc1</smiles>

Scheme 1. Synthesis of 4-(thiazol-2-yldiazenyl)phenol $\mathrm{L}_{1}$ and 2-((4hydroxyphenyl)diazenyl)-5-nitrophenol $\mathrm{L}_{2}$.

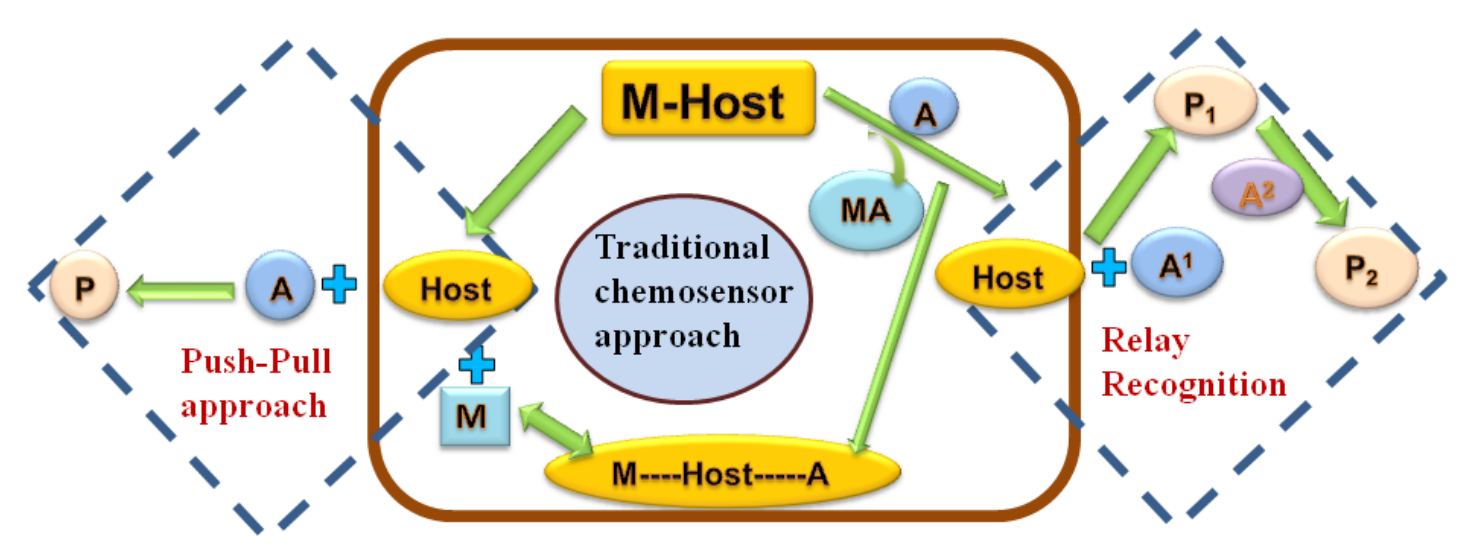

Fig.1. Illustration of "Anion Sensing". $A, A^{1}, A^{2}=$ Anions, $M=M e t a l, P, P_{1}, P_{2}=$ Product, MA= ion pair. 

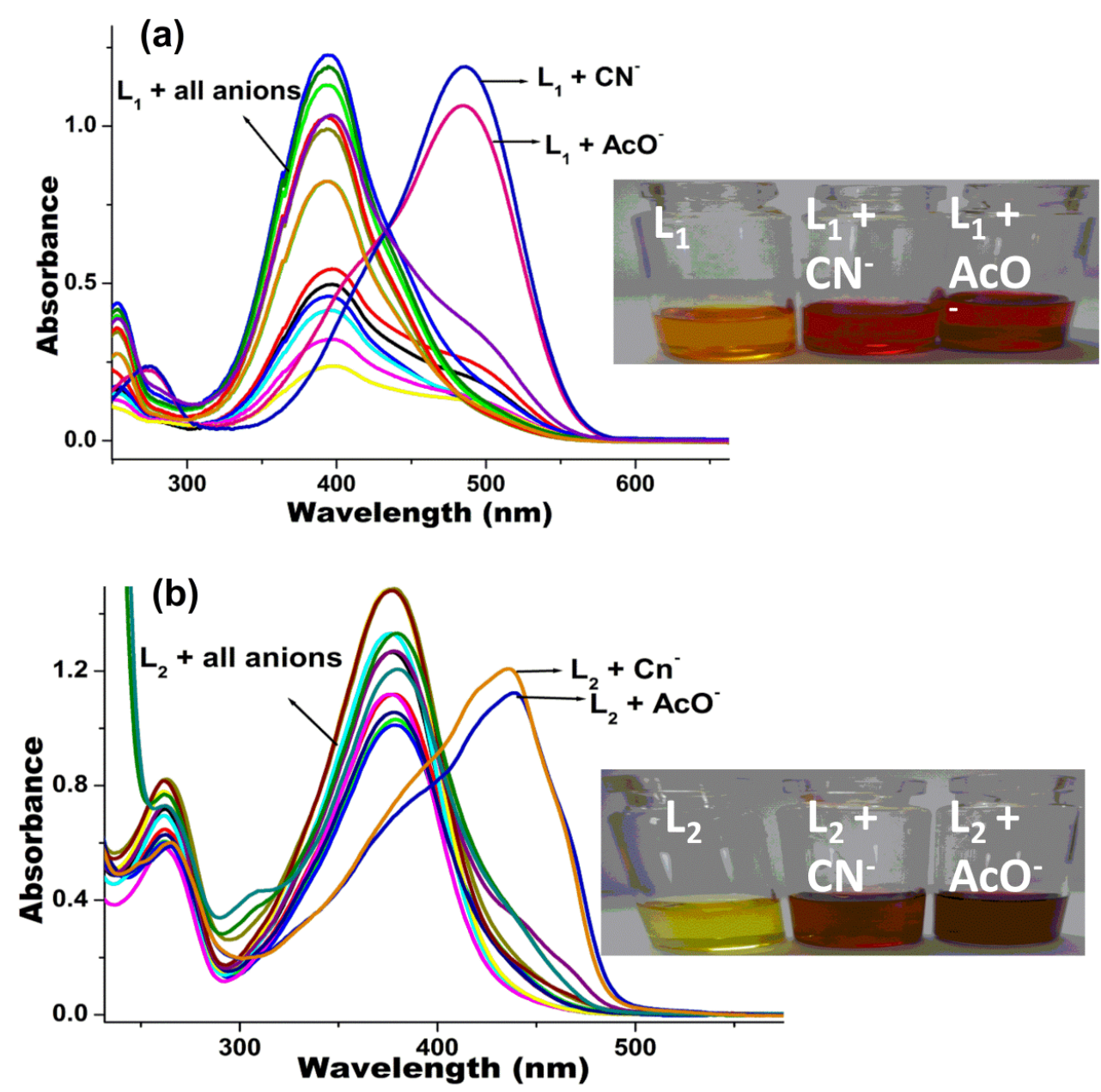

Fig.2. (a) Absorption spectra of $\mathrm{L}_{1}\left(20 \mu \mathrm{M}\right.$, DMSO/H $\mathrm{H}_{2} \mathrm{O}-\mathrm{HEPES}(\mathrm{v} / \mathrm{v} ; 1: 1, \mathrm{pH}=$ $7.3 \pm 0.2)$ solution) with a series of anions and sudden color change of $L_{1}$ with $\mathrm{CN}^{-}$and $\mathrm{AcO}^{-}$ion, (b) Absorption spectra of $\mathrm{L}_{2}\left(20 \mu \mathrm{M}, \mathrm{DMSO} / \mathrm{H}_{2} \mathrm{O}\right.$ -

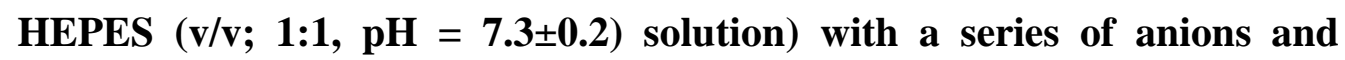
sudden color change of $\mathrm{L}_{2}$ with $\mathrm{CN}^{-}$and $\mathrm{AcO}^{-}$ion. 

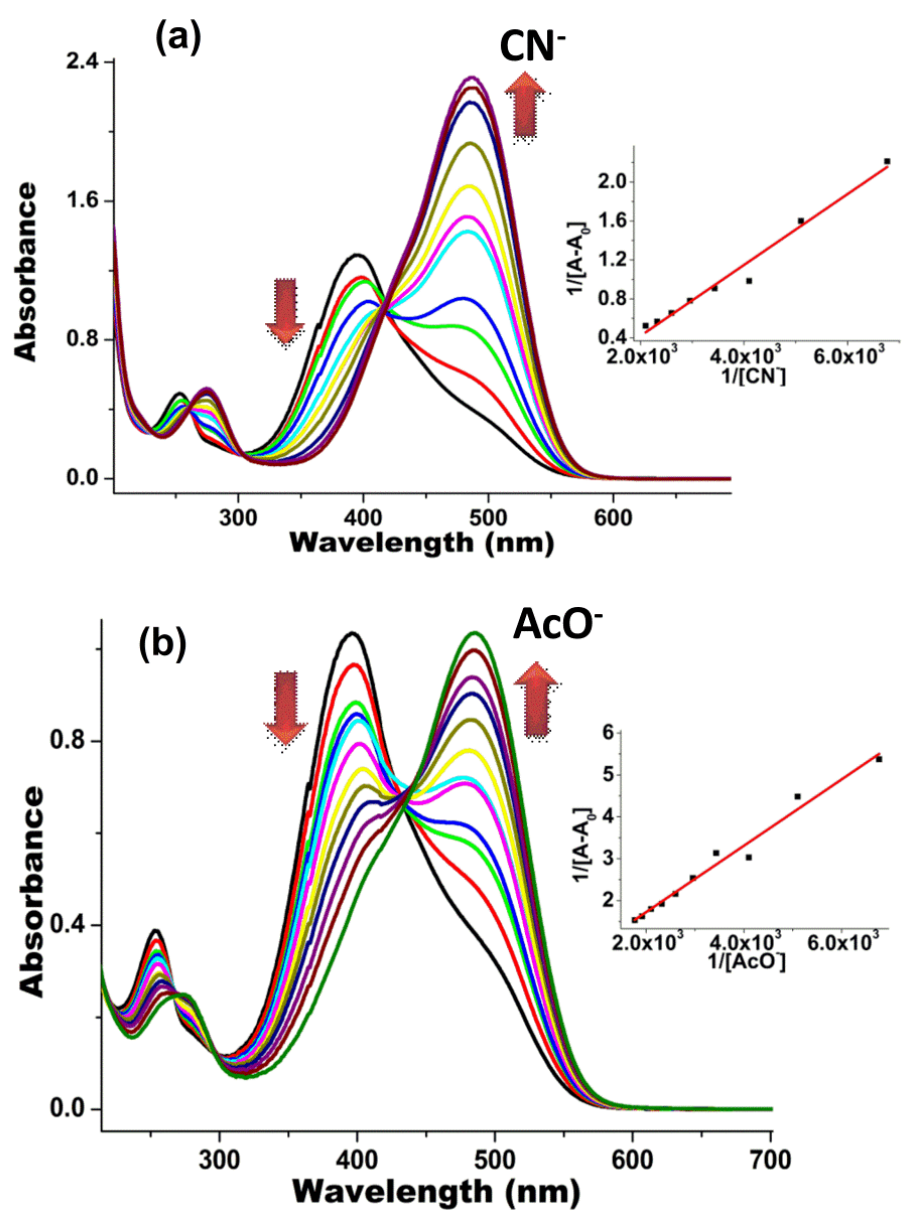

Fig.3. (a) Absorption spectra of $\mathrm{L}_{1}\left(20 \mu \mathrm{M}\right.$, DMSO/H $\mathrm{H}_{2} \mathrm{O}-\mathrm{HEPES}(\mathrm{v} / \mathrm{v} ; 1: 1, \mathrm{pH}=$ 7.3 \pm 0.2$)$ solution) changes with increasing amount of $\mathrm{CN}^{-}$ion $(0-100 \mu \mathrm{L})$, Inset shows $\mathrm{BH}$-plot of $\mathrm{L}_{1}$ with $\mathrm{CN}^{-}$ion, (b) Absorption spectra of $\mathrm{L}_{1}(20$ $\mu \mathrm{M}, \mathrm{DMSO} / \mathrm{H}_{2} \mathrm{O}-\mathrm{HEPES}(\mathrm{v} / \mathrm{v} ; 1: 1, \mathrm{pH}=7.3 \pm 0.2)$ solution) changes with increasing amount of $\mathrm{AcO}^{-}$ion (0-100 $\left.\mu \mathrm{L}\right)$, Inset shows BH-plot of $\mathrm{L}_{1}$ with $\mathrm{AcO}^{-}$ion. 

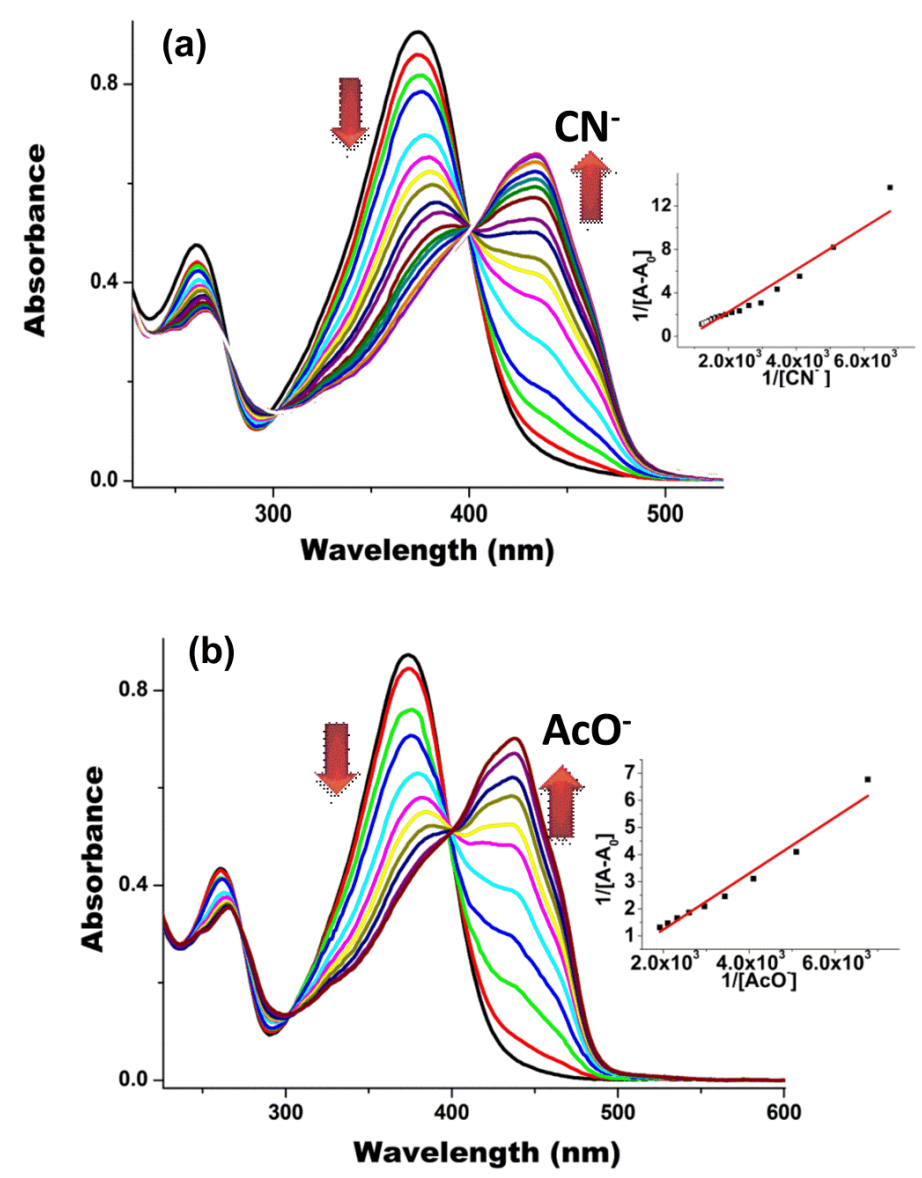

Fig.4. (a) Absorption spectra of $\mathrm{L}_{2}\left(20 \mu \mathrm{M}\right.$, DMSO/H $\mathrm{H}_{2} \mathrm{O}-\mathrm{HEPES}(\mathrm{v} / \mathrm{v} ; 1: 1, \mathrm{pH}=$

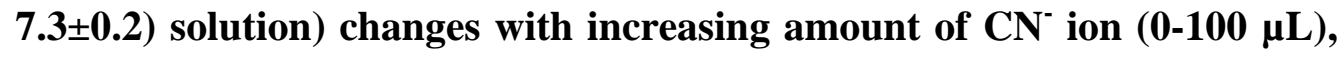
Inset shows BH-plot of $\mathrm{L}_{2}$ with $\mathrm{CN}^{-}$ion, (b) Absorption spectra of $\mathrm{L}_{2}(20$ $\mu \mathrm{M}, \mathrm{DMSO} / \mathrm{H}_{2} \mathrm{O}-\mathrm{HEPES}(\mathrm{v} / \mathrm{v} ; 1: 1, \mathrm{pH}=7.3 \pm 0.2)$ solution) changes with increasing amount of $\mathrm{AcO}^{-}$ion $(0-100 \mu \mathrm{L})$, Inset shows BH-plot of $\mathrm{L}_{2}$ with $\mathrm{AcO}^{-}$ion.
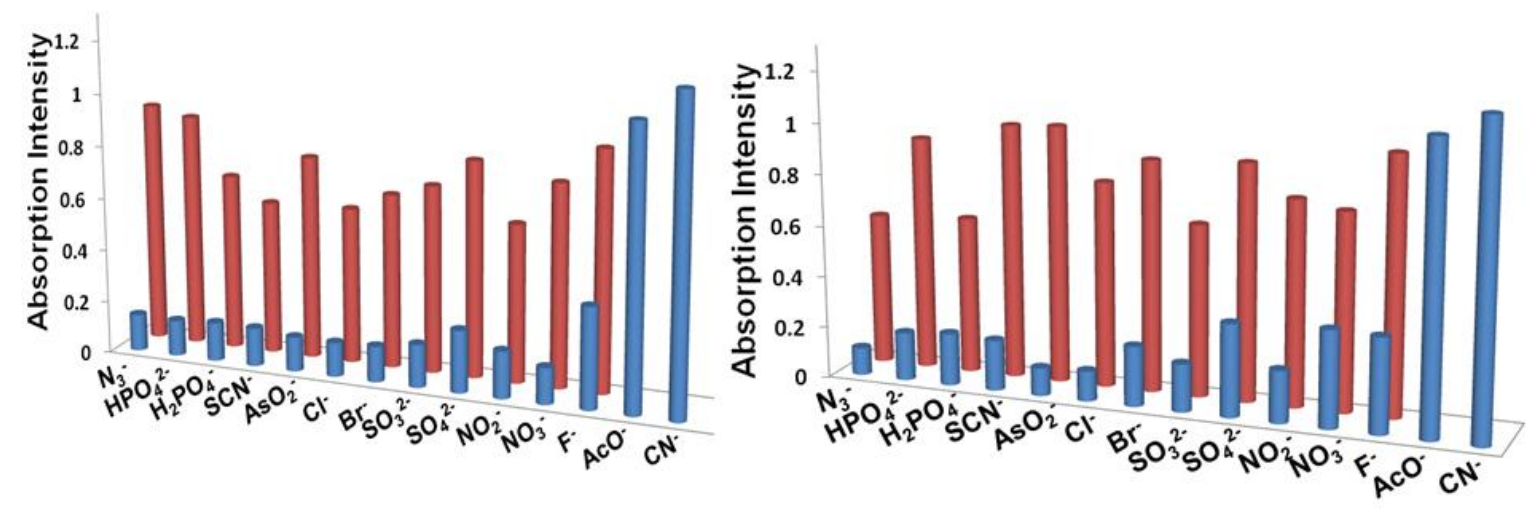

Fig.5. (a) Interference study of different anions with the selectivity of $L_{1}$ towards $\mathrm{CN}^{-}$ion (b) Interference study of different anions with the selectivity of $\mathrm{L}_{2}$ towards $\mathrm{CN}^{-}$ion. 


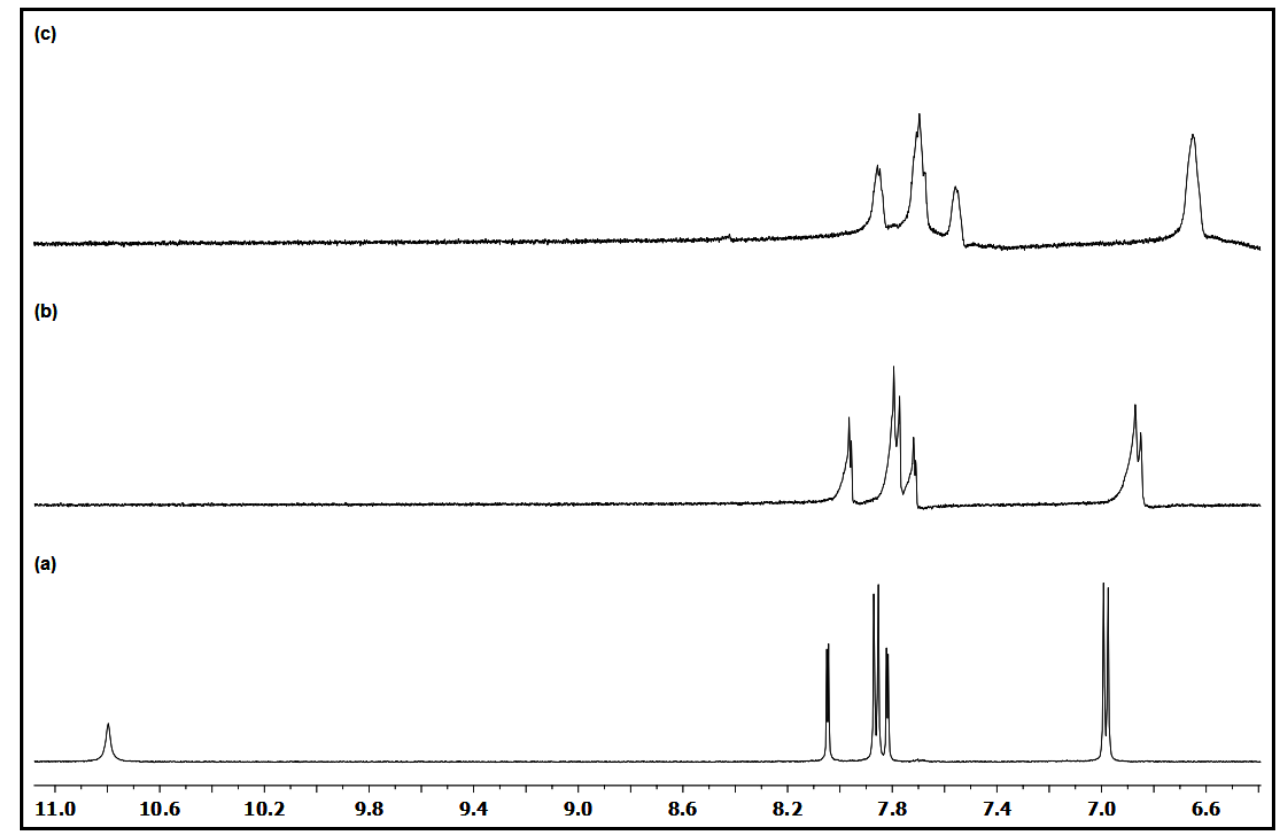

Fig.6. ${ }^{1} \mathrm{H}-\mathrm{NMR}$ titration of $\mathrm{L}_{1}$ with $\mathrm{CN}^{-}$ion in DMSO- $d_{6}$.

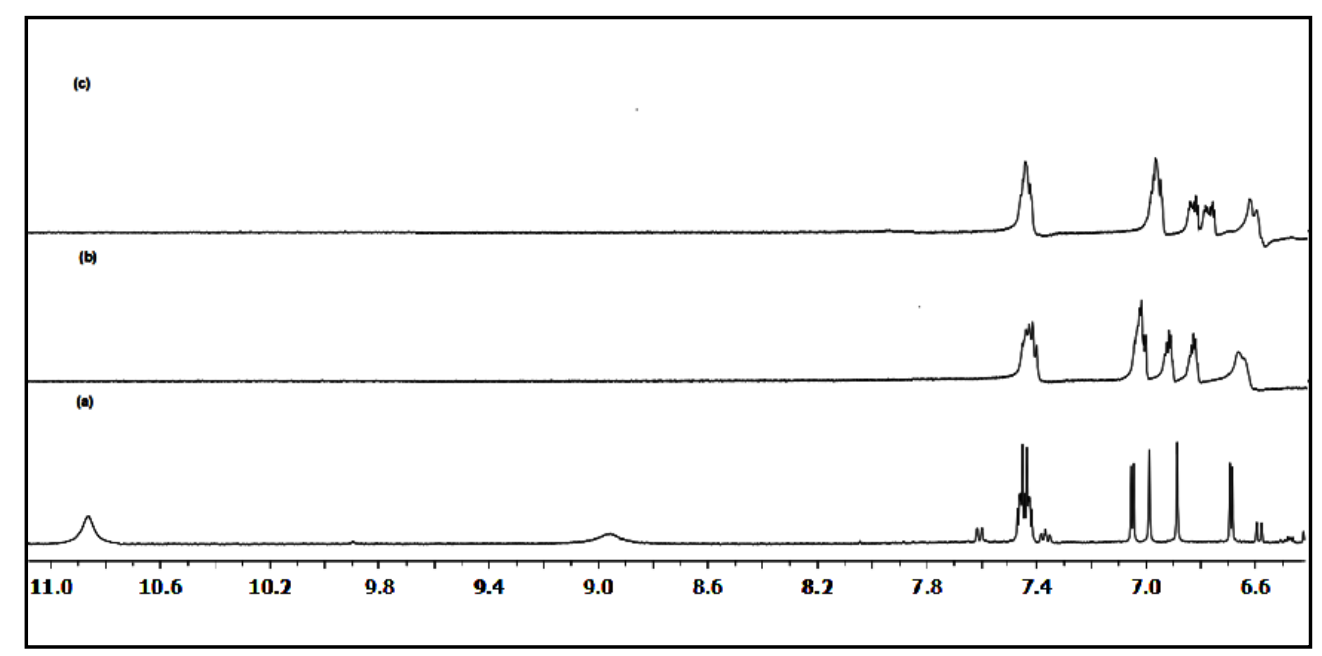

Fig.7. ${ }^{1} \mathrm{H}-\mathrm{NMR}$ titration of $\mathrm{L}_{2}$ with $\mathrm{CN}^{-}$ion in DMSO- $d_{6}$. 


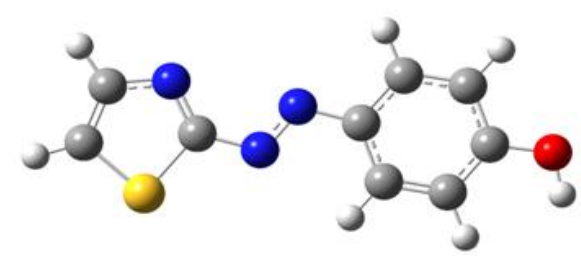

$\mathrm{L}_{1} \quad \Delta \mathrm{E}=\mathbf{2 . 3 6 2}$

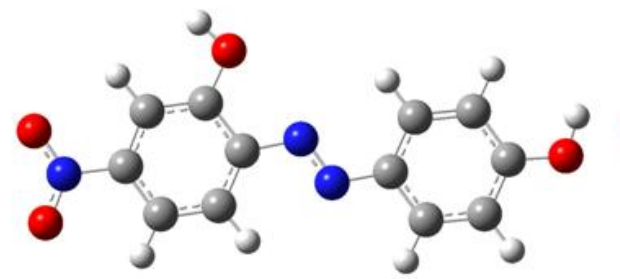

$\mathrm{L}_{2} \Delta \mathrm{E}=\mathbf{2 . 2 3 6}$

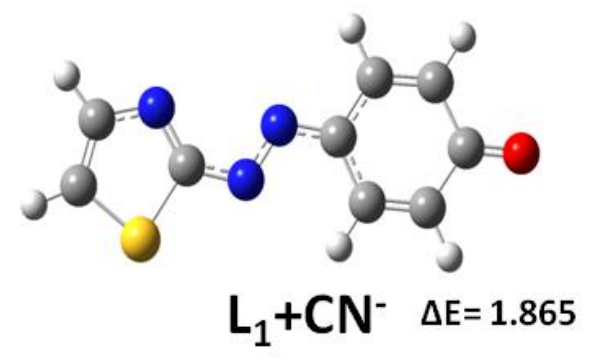

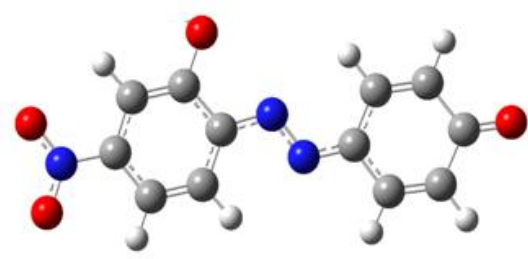

$\mathrm{L}_{2}+\mathrm{CN}^{-} \quad \Delta \mathrm{E}=1.773$

Fig.8. Optimized structure of $L_{1}$ and $L_{2}$ and their cyanide adduct.

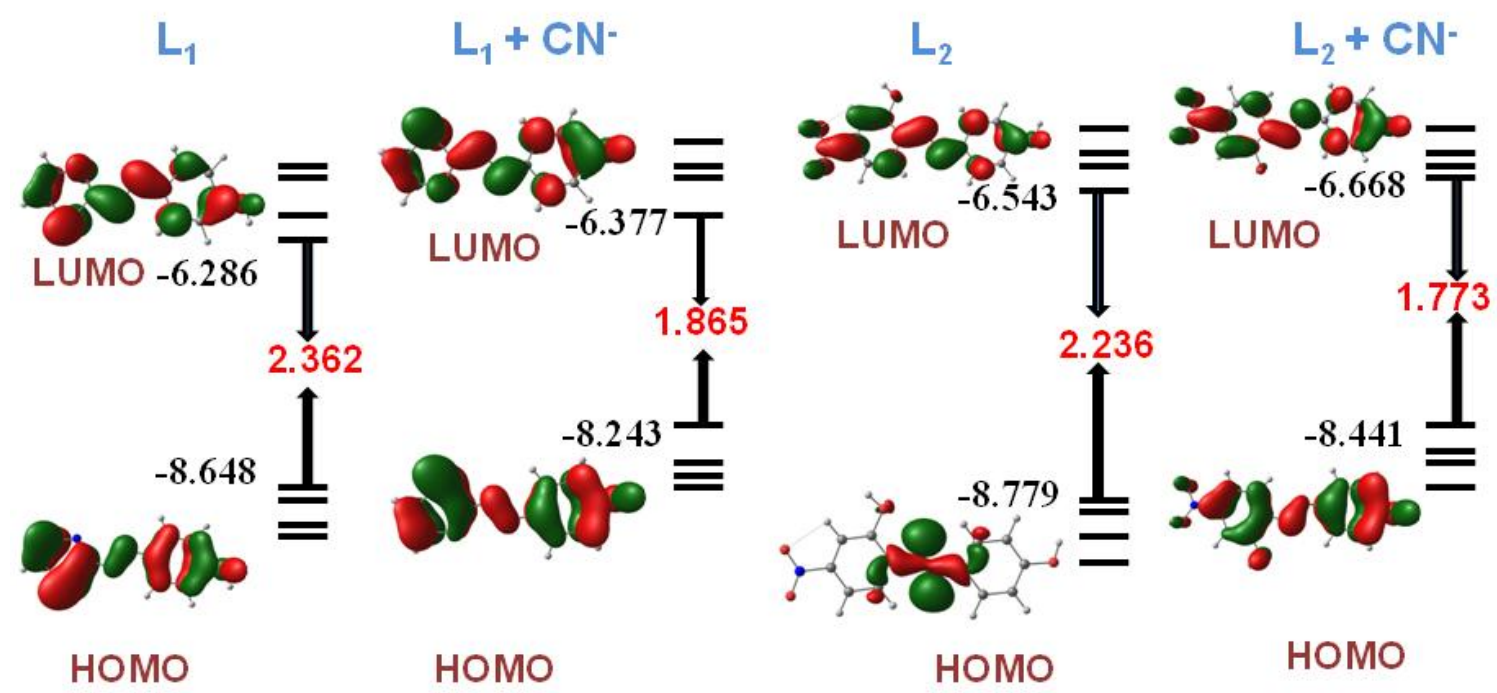

Fig.9. HOMO-LUMO energy diagram of $\mathrm{L}_{1}, \mathrm{~L}_{1}+\mathrm{CN}^{-}, \mathrm{L}_{2}$ and $\mathrm{L}_{2}+\mathrm{CN}^{-}$. 


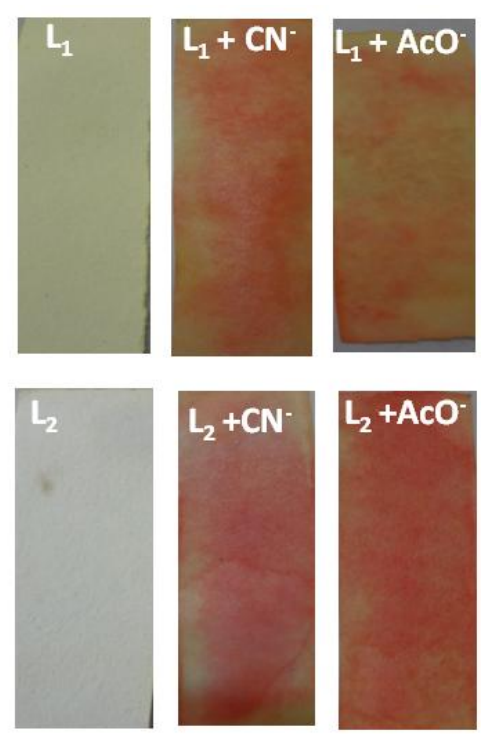

Fig.10. Photographs of test strips of $\mathrm{L}_{1}$ and $\mathrm{L}_{2}$ with $\mathrm{CN}^{-}$and $\mathrm{AcO}^{-}$ion.
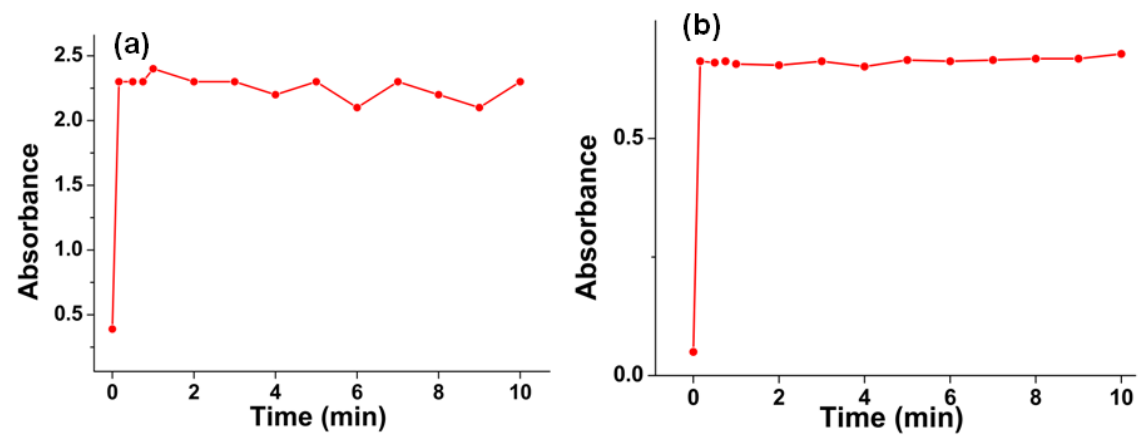

Fig.11. (a) Absorbance changes at $485 \mathrm{~nm}$ for $\mathrm{L}_{1}\left(20 \mu \mathrm{M}, 25^{\circ} \mathrm{C}\right)$ in a mixture of DMSO- $\mathrm{H}_{2} \mathrm{O}(1: 1, \mathrm{v} / \mathrm{v})$ after addition of $\mathrm{NaCN}$ (1mM) (b) Absorbance changes at $432 \mathrm{~nm}$ for $\mathrm{L}_{2}\left(20 \mu \mathrm{M}, 25^{\circ} \mathrm{C}\right)$ in a mixture of DMSO- $\mathrm{H}_{2} \mathrm{O}(1: 1$, $\mathrm{v} / \mathrm{v})$ after addition of $\mathrm{NaCN}(1 \mathrm{mM})$.

\section{$\underline{\text { Tables }}$}

Table 1. Stoichiometry, binding constant, detection limit values for obtained adduct of $\mathrm{L}_{1}$ and $\mathrm{L}_{2}$ with $\mathrm{CN}^{-}$and $\mathrm{AcO}^{-}$ions.

\begin{tabular}{llcccc}
\hline $\begin{array}{l}\text { S. } \\
\text { No. }\end{array}$ & $\begin{array}{l}\text { Receptor } \\
\text { + ions }\end{array}$ & Solvent & $\begin{array}{l}\text { Binding } \\
\text { Constant }\end{array}$ & Stoichiometry & $\begin{array}{l}\text { Limit of } \\
\text { Detection } \\
\text { (nM) }\end{array}$ \\
\hline 1. & $\mathrm{L}_{1}+\mathrm{CN}^{-}$ & $\begin{array}{c}\mathrm{DMSO} / \mathrm{H}_{2} \mathrm{O} \\
(1: 1)\end{array}$ & $1.6 \times 10^{3}$ & $1: 1$ & 87 \\
2. & $\mathrm{L}_{1}+\mathrm{AcO}^{-}$ & $\begin{array}{c}\mathrm{DMSO} / \mathrm{H}_{2} \mathrm{O} \\
(1: 1)\end{array}$ & $8.0 \times 10^{2}$ & $1: 1$ & 83 \\
3. & $\mathrm{L}_{2}+\mathrm{CN}^{-}$ & $\begin{array}{c}\mathrm{DMSO} / \mathrm{H}_{2} \mathrm{O} \\
(1: 1)\end{array}$ & $8.4 \times 10^{3}$ & $1: 2$ & 81 \\
4. & $\mathrm{L}_{2}+\mathrm{AcO}^{-}$ & $\begin{array}{c}\mathrm{DMSO} / \mathrm{H}_{2} \mathrm{O} \\
(1: 1)\end{array}$ & $1.7 \times 10^{2}$ & $1: 2$ & 89 \\
\hline
\end{tabular}


Table 2. Energy of HOMO-LUMO of $\mathrm{L}_{1}, \mathrm{~L}_{2}$ and Complexes.

\begin{tabular}{lccc}
\hline Receptor + ions & HOMO $(\mathbf{e V})$ & LUMO $(\mathbf{e V})$ & $\Delta \mathrm{E}(\mathbf{e V})$ \\
\hline $\mathbf{L}_{\mathbf{1}}$ & -8.648 & -6.286 & 2.362 \\
$\mathbf{L}_{\mathbf{1}}+\mathbf{C N}^{-}$ & -8.243 & -6.377 & 1.865 \\
$\mathbf{L}_{\mathbf{2}}$ & -8.779 & -6.543 & 2.236 \\
$\mathbf{L}_{\mathbf{2}}+\mathbf{C N}^{-}$ & -8.441 & -6.68 & 1.773 \\
\hline
\end{tabular}

